\title{
Comparative analysis of the song of the Rufous-collared Sparrow Zonotrichia capensis (Emberizidae) between Campinas and Botucatu, São Paulo State, Brazil
}

\author{
MÁRCIO F. AVELINO and JACQUES M.E. VIELLIARD* \\ Laboratório de Bioacústica, Instituto de Biologia, Universidade Estadual de Campinas \\ Cx. Postal 6109, 13083-970 Campinas, SP, Brasil \\ Manuscript received on January 15, 2004; accepted for publication on February 5, 2004.
}

\begin{abstract}
The regional dialects or regiolects of the Rufous-collared Sparrow Zonotrichia capensis were compared

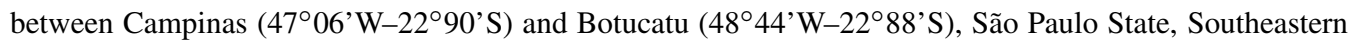
Brazil. Songs of 88 individuals from thirteen localities were recorded. Sonograms showed that two areas presented more homogeneous songs, forming two regiolects. In 11 localities most individuals shared the same song type. At the other two localities, they sang up to 5 different song types. This occurs at the boundaries of the regiolects, and was also where individuals singing more than one song type were found. Similarities between song types were not related to geographic distance between the respective singers. A comparative analysis showed similarities in these regiolects with song of populations from Northeastern Brazil.
\end{abstract}

Key words: bioacoustics, geographic variation, Zonotrichia capensis, birds, São Paulo State, Brazil.

\section{INTRODUCTION}

Studies on vocal learning in birds have been mostly done on a few species of oscines, where individuals need a model and intact hearing for normal song development to occur (Konishi 1989). The two most obvious consequences of vocal learning are larger (sometimes enormous) song repertoires and learned song dialects (Kroodsma 1996).

Studies of geographic song variation and vocal dialects have been conducted for a long time in North America, mostly on the White-crowned Sparrow Zonotrichia leucophrys (Baker 1974, Baptista 1977). Argentine populations of its Neotropical relative, the Rufous-collared Sparrow Zonotrichia capensis, were studied by Nottebohm (1975), but

\footnotetext{
*Member of Academia Brasileira de Ciências Correspondence to: Jacques M.E. Vielliard E-mail: jacques@unicamp.br
}

the Brazilian populations of this species are little known.

In the present study, we analyzed the geographic variation of the song of Zonotrichia capensis in an area of Southeastern Brazil.

\section{MATERIALS AND METHODS}

The study area was the region between the cities of Campinas (47 $\left.06^{\prime} \mathrm{W}-22^{\circ} 90^{\prime} \mathrm{S}\right)$ and Botucatu (48 $44^{\prime}$ W-22 ${ }^{\circ} 88^{\prime}$ 'S), São Paulo State, Southeastern Brazil. Thirteen localities were visited (Fig. 1) between these cities and the songs recorded with a Sony TCD-D10 or a Tascam DA-P1 digital taperecorder, and a cardioid Beyer M88N microphone mounted in an acoustic parabola (60 cm diameter). All recordings were made in disturbed suburban or rural areas, where this species is well adapted and commonly found. 
Sonograms of the songs were obtained using the Cool Edit Pro software. The most common song on each locality was selected as the song type for that locality. The comparisons between the sonograms were made with the Matlab software, programmed to calculate the similarity between images. All the measurements were done between pairs of notes that occupy the same sequential position in the song. Correlation values between different songs were calculated as the average of the correlation values measured between their notes.

\section{RESULTS}

Eighty-eight individuals were recorded (Table I). The song of Zonotrichia capensis found in this region showed usually five simple notes. In the localities of Campinas and Piracicaba the song-type had four notes and near Tietê, six notes. All songs are made only of simple notes, i.e. softly modulated whistles without harmonics (Fig. 2).

Comparison of the sonograms showed the existence of two areas where the songs were more homogeneous, forming two regiolects. Around these two areas with low variability there were areas with high variability, with up to seven different song-types (Fig. 1). The modulation, either ascending or descending, of the notes of the initial part of the songs allowed to easily differentiate the two dialects, inclusively in the areas with various song-types. Thus, the eastern dialect was characterized by descending initial notes, and the western dialect by ascending initial notes (Fig. 2).

The localities with homogeneous song-types were Sumaré, Monte Mor, Capivari, Tietê, Pardinho and Conchas. The localities with high variability of song-types were Campinas, Rio das Pedras, Piracicaba and Botucatu. The localities from Americana and Anhembi too were in the high variability area, but few individuals were found, all singing a different song-type and thus making it impossible to determine a song-type to represent the locality. Individuals that can sing more than one song-type were found and all were in localities in the high variability area.
Songs from our study area were compared with songs in the Arquivo Sonoro Neotropical from other localities in Brazil. High similarity was found between songs from Monte Mor and Campos do Jordão (São Paulo State) and between Conchas, Pardinho and Macururé (Bahia State). Thus, it appears that the geographic distance is not a good factor to predict the variation of song structure.

\section{DISCUSSION}

The structure of the song of the populations of the Rufous-collared Sparrow from the studied areas has a very simple modulation and few notes. This characteristic differs from the songs of $Z$. leucophrys, which have more elaborate structures, including differentiated segments with buzzes, complex notes, simple notes and whistles (Baptista 1977, Baptista and King 1980).

The songs of the population of Rufous-collared Sparrow from Argentina, studied by Nottebohm (1975), are similar to the songs recorded in the study area, except for presenting a buzz at the end of the song.

In general, correlations between first notes and between last notes were high. Sometimes the last note was repeated. The songs varied, mainly, in their central part. In this aspect, this population of $Z$. capensis resemble the population of Z. leucophrys studied by Baptista, which showed the greatest variation in the complex notes of the central part of the song (Baptista 1977).

The difference in the modulation of the initial notes was used to determine the dialects. The similarity analysis of the sonograms, made with the Matlab software, showed this characteristic to be consistent enough to categorize the song-types. Moreover, the existence of two areas where the songs are homogeneous, encircled by areas where songs present high variation, confirms the recognition of two dialects.

The high variation area corresponds to the border area of the dialects, probably because of exchanges and interactions between these populations. Z. leucophrys from North America showed hybrid 


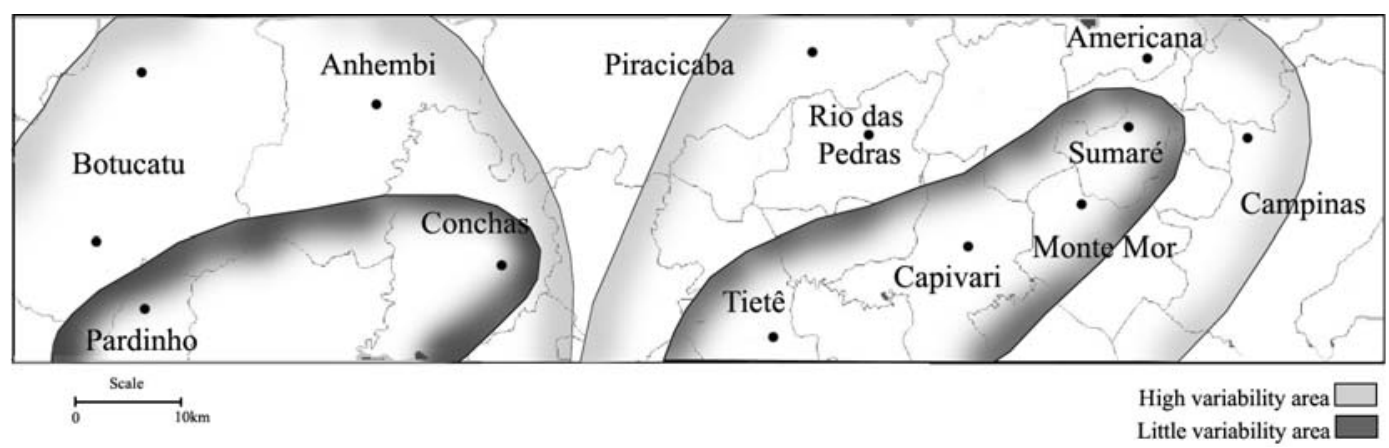

Fig. 1 - Distribution of the dialects in the study area.

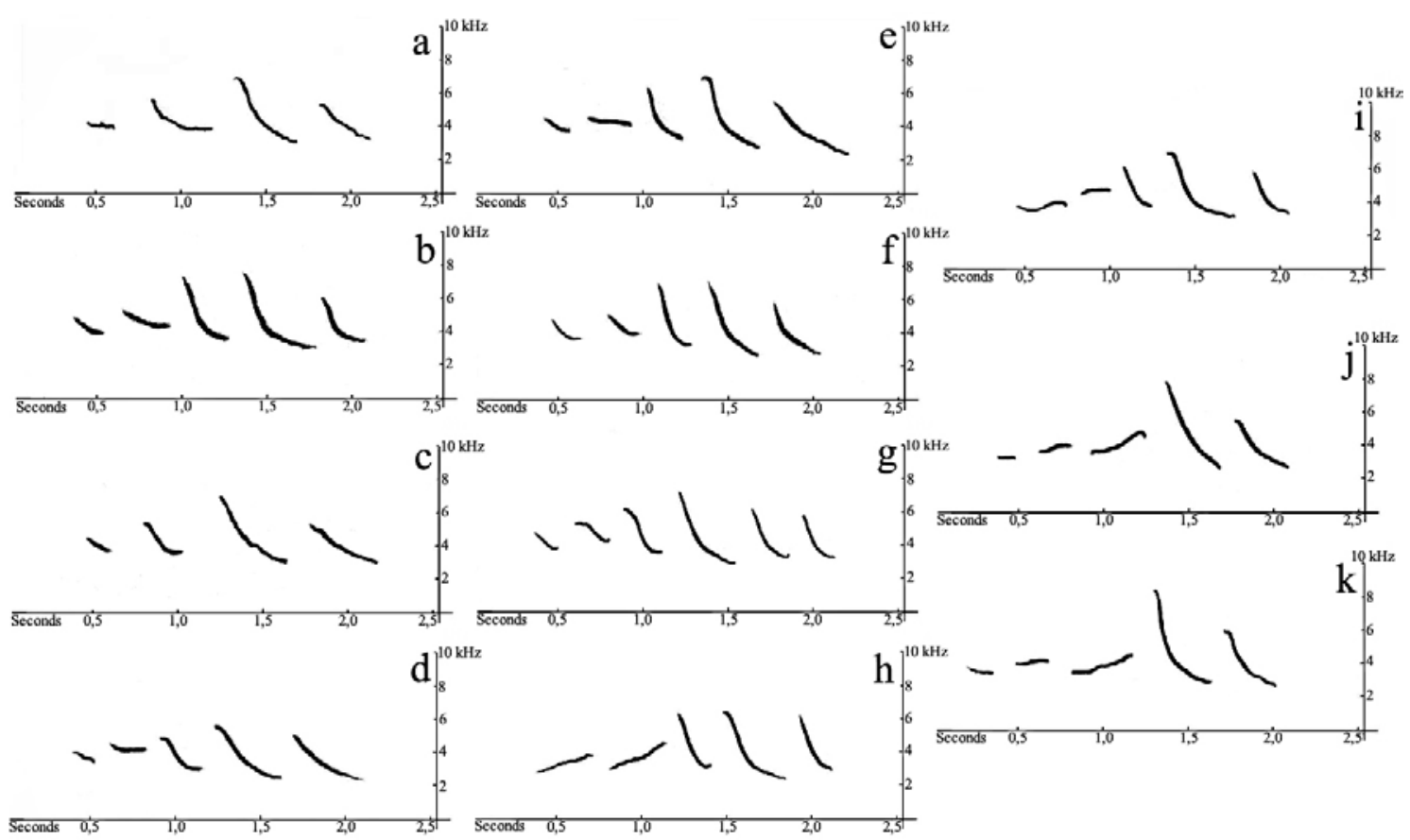

Fig. 2 - Sonograms of the typical or sole song-type from each studied locality: a. Campinas, b. Monte Mor, c. Piracicaba, d. Rio das Pedras, e. Sumaré, f. Capivari, g. Tietê, h. Pardinho, i. Conchas, j. Lageado (Botucatu), k. Rubião Júnior (Botucatu). Scale of time: $2.5 \mathrm{~s}$. Scale of frequency: $0-10 \mathrm{kHz}$.

songs in the border area between dialects (Baker 1974, Baker and Thompson 1985, Baptista and King 1980), but hybrid songs were not found in Z. capensis; perhaps the simple structure of its song cannot reflect its hybrid origin.

Individuals singing two song-types were found in areas of high variability only, suggesting that they were in contact with both dialects during their learning process.

The comparisons between songs from individuals separated by a long distance showed a high similarity between some songs recorded in our study area and songs from other regions in Brazil. For instance, the song-type from Monte Mor showed 75\% similarity with a song from Campos do Jordão, São Paulo State, $189 \mathrm{~km}$ apart, and the song-types from 
TABLE I

Individuals recorded and the song-types from the different localities.

\begin{tabular}{|c|c|c|c|c|c|c|c|c|}
\hline \multirow{3}{*}{$\begin{array}{l}\text { Locality } \\
\text { Campinas }\end{array}$} & \multirow{3}{*}{$\begin{array}{c}\begin{array}{c}\text { Individuals } \\
\text { recorded }\end{array} \\
14\end{array}$} & \multirow{3}{*}{$\begin{array}{c}\begin{array}{c}\text { Recording time } \\
\text { (minutes:seconds) }\end{array} \\
59: 44\end{array}$} & \multicolumn{6}{|c|}{$\begin{array}{l}\text { Song-types and number of singers } \\
\text { of each one }\end{array}$} \\
\hline & & & $30 \mathrm{i}$ & $04 \mathrm{ac}$ & $04 b c$ & $34 \mathrm{i}$ & $32 \mathrm{i}^{*}$ & $08 c^{*}$ \\
\hline & & & 9 & 1 & 1 & 1 & 1 & 1 \\
\hline \multirow[t]{2}{*}{ Sumaré } & \multirow[t]{2}{*}{4} & \multirow[t]{2}{*}{$23: 32$} & \multicolumn{6}{|c|}{01 ii } \\
\hline & & & \multicolumn{6}{|c|}{4} \\
\hline \multirow[t]{2}{*}{ Americana } & \multirow[t]{2}{*}{7} & \multirow[t]{2}{*}{$20: 15$} & $06 \mathrm{ii}$ & $1 \mathrm{c}$ & \multicolumn{2}{|c|}{ 07ii } & $08 \mathrm{ii}$ & $3 c$ \\
\hline & & & 2 & 2 & \multicolumn{2}{|c|}{1} & 1 & 1 \\
\hline \multirow[t]{2}{*}{ Capivari } & \multirow[t]{2}{*}{4} & \multirow[t]{2}{*}{$15: 36$} & \multicolumn{6}{|c|}{$47 i$} \\
\hline & & & \multicolumn{6}{|c|}{4} \\
\hline \multirow[t]{2}{*}{ Monte Mor } & \multirow[t]{2}{*}{4} & \multirow[t]{2}{*}{$26: 39$} & \multicolumn{6}{|c|}{$44 i$} \\
\hline & & & \multicolumn{6}{|c|}{4} \\
\hline \multirow[t]{2}{*}{ Rio das Pedras } & \multirow[t]{2}{*}{5} & \multirow[t]{2}{*}{ 19:35 } & \multicolumn{2}{|c|}{$23 \mathrm{ii}$} & \multicolumn{2}{|c|}{$20 \mathrm{ii}$} & \multicolumn{2}{|c|}{$25 \mathrm{ii} *$} \\
\hline & & & . & 3 & \multicolumn{2}{|c|}{1} & & I \\
\hline Piracicaba & 8 & 33:00 & 11ii & $17 \mathrm{ii}$ & & & $18 \mathrm{ii}$ & 14ii* \\
\hline & & & 4 & 1 & & & 1 & 1 \\
\hline Tietê & 6 & $18: 12$ & & & & iii & & \\
\hline & & & & & & 5 & & \\
\hline Conchas & 4 & $12: 09$ & & & & iii & & \\
\hline & & & & & & 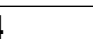 & & \\
\hline Anhembi & 5 & 16:00 & & $\mathrm{c}$ & 36iii & $38 \mathrm{iii}$ & & $\mathrm{ii}^{*}$ \\
\hline & & & 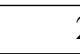 & & 1 & 1 & & t \\
\hline Pardinho & 12 & $37: 15$ & & aiii & & & & iii \\
\hline & & & 1 & 0 & & & & L \\
\hline Lajeado & 6 & $16: 31$ & & iii & & & & ii \\
\hline & & & & & & & & t \\
\hline Rubião & 9 & 39:09 & & iii & 02iii & 08iii* & & $\mathrm{ii}^{*}$ \\
\hline & & & & 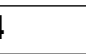 & 2 & 2 & & L \\
\hline Total & 88 & $5: 37: 37$ & & & & & & \\
\hline
\end{tabular}

In bold: song-type more common in the locality. *Individuals with two song-types.

Pardinho and Conchas showed respectively $74 \%$ and $77 \%$ similarity with a song from Macururé, Bahia State, at a distance of more than $1800 \mathrm{~km}$.

\section{CONCLUSIONS}

This research shows that there are two regional dialects in the study area. The discriminant character is the initial notes of the song, which can ascend or descend in frequency. We found areas with high variability of the song-types uttered by neighbors and areas with homogeneous song-types between local singers. The higher variability areas correspond to the boundary areas of regiolects. Birds that showed two song-types were found only in areas of high song-type variability. Geographic distance is not related to the structural similarity of the songs. 


\section{ACKNOWLEDGMENTS}

We thank FMB/FUNCAMP and FAEP/UNICAMP for financial and academic support.

\section{RESUMO}

Nesta pesquisa foram analisados os dialetos do Tico-tico Zonotrichia capensis que ocorrem entre Campinas e Botucatu, Estado de São Paulo, Sudeste do Brasil. Treze localidades foram visitadas e os cantos de 88 indivíduos gravados com um gravador DAT (Digital Audio Tape) e um microfone cardióide montado em uma parábola acústica. Comparações de sonogramas mostraram a existência de duas áreas onde os cantos foram mais homogêneos, formando dois dialetos. Em 11 localidades, muitos indivíduos compartilham o mesmo tipo de canto. Em outras duas localidades, houve até cinco tipos diferentes de cantos. Isto ocorreu nas fronteiras dos dialetos e onde foram encontrados indivíduos cantando mais que um tipo de canto. A similaridade entre os tipos de canto não está relacionada com a distância geográfica entre os cantores. Comparações foram feitas também com gravações de outras localidades do Brasil e similaridades foram encontradas com cantos de aves de localidades como Conchas e Macururé, na Bahia, distantes mais de 1800 km.

Palavras-chave: bioacústica, variação geográfica, Zonotrichia capensis, aves, Estado de São Paulo, Brasil.

\section{REFERENCES}

BAKER MC. 1974. Song dialects and genetic differences in White-crowned Sparrows (Zonotrichia leucophrys). Evolution 29: 226-241.

Baker MC And Thompson DB. 1985. Song dialects of White-crowned Sparrows: historical processes inferred from patterns of geographic variation. Condor 87: 127-141.

BAPTISTA LF. 1977. Geographic variation in song and dialects of the Puget Sound White-crowned Sparrow. Condor 79: 356-370.

BAPTISTA LF AND KING JR. 1980. Geographical variation in song and song dialects of montane White-crowned Sparrows. Condor 82: 267-284.

Konishi M. 1989. Birdsong for neurobiologists. Neuron 3: $541-549$.

KRoodSMa DE. 1996. Ecology of passerine song development. In: Kroodsma DE and Miller EH (Ed), Ecology and evolution of acoustic communication in birds. Ithaca: Cornell University Press, p. 3-19.

Nоттевонм F. 1975. Continental patterns of song variability in Zonotrichia capensis: some possible ecological correlates. Am Nat 109: 605-624. 